\title{
Poverty and Inequality in Mexico after NAFTA: Challenges, Setbacks and Implications
}

\author{
Emmanuel Alvarado*
}

\begin{abstract}
This article analyzes the progress obtained in diminishing poverty and inequality in Mexico during the post-NAFTA years ranging from 1994 to 2007, and how it pertains to the broad critical debate surrounding poverty-gap reduction in the context of regional and international economic integration and trade liberalization. Specifically, the article discusses the evolution of Mexican rural and urban poverty, income and regional disparities, as well as the role of government spending after the enactment of NAFTA and within the framework of economic liberalization marked by expanded international trade and investment, particularly with the United States.

Keywords: NAFTA, poverty, inequality, Mexico, immigration
\end{abstract}

Resumen. Este artículo analiza el progreso logrado en la disminución de la pobreza y la inequidad en México durante los años posteriores a la firma del Tratado de Libre Comercio, desde 1994 al 2007, y su relación inherente al debate académico en torno a la reducción de la pobreza en un contexto de integración económica regional y liberalización comercial internacional. Específicamente, en el artículo se examina la evolución de la pobreza urbana y rural en México, las disparidades internas regionales y de ingreso, así como también el rol del gasto gubernamental después del inicio del Tratado de Libre Comercio dentro de un marco de liberalización económica marcado por una expansión de flujos comerciales y de inversión con Estado Unidos.

Palabras Clave: TLCAN, pobreza, inequidad, México, migración económica

* Florida Atlantic University, Boca Raton, Florida. Department of Comparative Studies. Email: ealvarado@fau.edu 


\section{Mexico's Poor: Contextualizing Poverty and Inequality in the post-NAFTA years}

Few topics in the history of the political economy have drawn so much debate as that of the proper fashion to deal with poverty and inequality. In our current modus operandi, we function internationally within the paradigm of a neoliberal economic model, one which argues for and privileges the opening of national economies to international trade and investment with only marginal interference from national governments as a qualification to reduce poverty levels in the long run. Within this framework, Milton Friedman pointed out that "...the scope of government must be limited. Its major function must be to protect our freedom both from enemies outside our gates and from our fellow citizens: to preserve law and order, to enforce private contracts, to foster competitive markets" (Friedman, 1962: 2). These guidelines constitute today what Galbraith (1976) described in Affluent Society as "conventional wisdom", that is, a set of social ideas which enjoys wide acceptability and is used to interpret and evaluate our social state of affairs.

Given the widespread presence of global poverty and the persistent inequality between and within countries in the midst of current stress placed on the efficient global allocation of productive resources, Galbraith's assessment of inequality, dating back to 1958, still occupies relevance today within the public debate: "Increasing aggregate output leaves a self-perpetuating margin of poverty at the very base of the economic pyramid... we need only to notice that, as an economic and social concern, inequality has been declining in urgency and this has had its reflection in the conventional wisdom"(p. 81). While the neoliberal set of guidelines enjoy relatively broad acceptance in various political and economic academic circles, they have also drawn, perhaps both rightly and wrongly so, criticism from anti-globalization groups, CNN pundit Lou Dobbs and prominent scholars like Noam Chomsky. Lou Dobbs has characterized free trade as a development harming middle class Americans and has been successful in bringing the matter to the attention of the American public sphere. In his book, War on the Middle Class, he cites Mark Weisbrot in arguing against globalization trends: 
We have had a 30-year period in which the real median wage has grown 9 percent, while productivity is up 80 percent. Almost none of that improvement has gone to the majority of the labor force. If you have competition with people who are paid very low wages and have no right to organize unions, you will have downward pressure on [wage] prices. The downward pressure on wages is critically hurting most employees in this country more than cheaper goods are helping them (Dobbs, 2006: 107).

On the other hand, Chomsky argues that the leading "globalization" institutions are keen on advantaging the affluent interest groups and multinational corporations: "Globalization that does not prioritize the rights of people will very likely degenerate into a form of tyranny, perhaps oligarchic and oligopolistic, based on concentrations of tightlylinked state-private power, largely unaccountable to the public" (Chomsky cited in Ahmed, 2006: 111). Dobbs' and Chomsky's claims about globalization and free trade are still a matter of relevant rational critical debate which mandate, in essence, a comprehensive and contextual analysis of the evolution of poverty and inequality.

Certainly, one of the locations where rigidly unequal social structures have been historically linked to the maintenance and perpetuation of poverty is Latin America in general, and Mexico in particular. Bean and Lowell (2004) have pointed out that as Mexico joined NAFTA in 1994, one of the hopes on both sides of the U.S.-Mexico border was that increasing economic integration with the U.S. through trade and investment linkages, a process already occurring even before NAFTA, would aid in improving living standards and employment in Mexico, and thus reduce unauthorized immigration. Article 102 of the agreement, as summarized by Hufbauer and Schott (2005), effectively incorporates increasing employment, improving working conditions and living standards as an official objective of the agreement. In relation to this explicit goal of the treaty, this article analyzes the progress obtained in diminishing poverty and inequality in Mexico during the period following the consolidation of economic liberalization, ranging from the early nineties to the present, and how it pertains to the broad rational critical debate surrounding poverty- 
gap reduction in the context of regional economic integration and trade liberalization.

While carrying out our analysis, it is difficult to isolate the effect of NAFTA, or economic liberalization specifically, given that the economic system is a complex web of interconnected factors and events. For example, as argued by Hufbauer and Schott (2005), Mexico faced two financial crises, one in 1983 and in 1995, which had a devastating effect on poverty levels and are more related to mismanagement of macroeconomic policy than to the process of economic liberalization. In addition to this, the persistence in Mexico of large income disparities between the white and lighter skinned population versus the indigenous population, also linked to the urban-rural divide, also seems prevalent much before the enactment of NAFTA and not necessarily a result of it. Thus, our analysis centers on providing a wider context regarding the evolution of poverty and inequality in Mexico during the post-liberalization years rather than strictly because of liberalization itself.

While tackling the issue of poverty, it becomes relevant to ask oneself, how can we effectively measure it? This question has been recently addressed in the New Yorker by Cassidy (2006) as the U.S. Census Bureau continues to build its estimation of the national poverty line using the methodology proposed by Mollie Orshansky in 1962, which was based on subsistence budgets of various family sizes in relation to the pretax family incomes. Instead, Cassidy (2006) proposes revising the methodology to also reflect taxes, benefits, medical costs as well as inequality between lower and higher income groups. The discussion regarding the effective way to measure poverty and depravation has been en vogue since Adam Smith's Wealth of Nations. Specifically, while discussing the measurement of poverty, Adam Smith considered it in relation to basic necessities within the broad social and cultural context: "By necessaries I understand not only the commodities which are indispensably necessary for the support of life, but what ever the customs of the country renders it indecent for creditable people, even the lowest order, to be without" (as cited in Cassidy, 2006: 19).

In relation to the measurement of poverty in Latin America, and of Mexico specifically, one of the most comprehensive methodologies, 
allowing for international comparisons, is included within the Social Panorama Report of the Economic Commission for Latin America and the Caribbean (ECLAC), one of the regional UN commissions. The methodology for classifying someone as poor takes into account the cost of basic needs in relation to per capita income of households, while considering countries' and regions' consumption habits, as Adam Smith suggested. The ECLAC report (2005) also includes an indigence indicator, which takes into account not the basic cost of overall needs but rather the overall cost of nutritional needs only, thus reflecting the proportion of the population not being able to satisfactorily meet nutritional needs.

In Figure 1, we observe the proportion of the Mexican population living below the ECLAC poverty and indigence level. There are two major elements which can be observed from the graph. The first is that the 1995 peso crisis had a substantial negative effect on the poverty level of the country. The second is that the poverty levels decreased most during the 1996-2000 period in which the U.S. economy was expanding rapidly along with Mexico's exports. The reduction of poverty has been relatively slower after the American economic slowdown between 2001-2004. Bensusan (2004) argued that trade and investment integration, especially after NAFTA, under Mexico's export-led growth has deepened Mexico's vulnerability to economic fluctuations in the U.S. While the overall poverty rate has decreased since 1989 according to the ECLAC study, it remains high at slightly less than a third of the total population.

In regards to the reduction of inequality, not much has improved during the post-NAFTA years in relation to previous decades. The most common method used to measure inequality is the Gini coefficient which ranges from 0 (absolute equality) to 1 (absolute inequality) and is highly sensitive to concentrations of income in higher income deciles. The Gini coefficient varies considerably across countries, according to the UNDP Development Report (2006) the U.S has a higher coefficient (.40) in relation to most industrialized nations like Japan (.25) or EU countries like Germany (.28) or even Canada (.26). Mexico's Gini coefficient is relatively higher to that of the U.S. and similar to other Latin American nations like Argentina (.53) or Peru (.55). In Figure 2, we 
Figure 1.

Poverty and indigence as a proportion of Mexican population

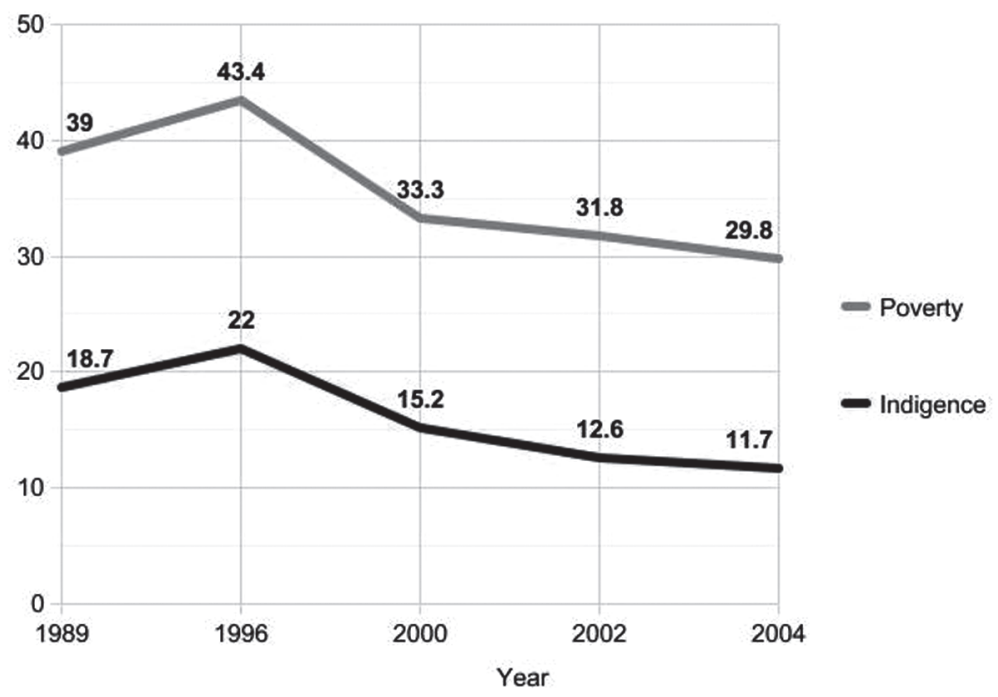

Source: Economic Comission for Latin America and the Caribbean.

see the evolution of the Gini coefficient since 1950. Inequality has a long presence in Mexican economic history and the years following the consolidation of economic openness since the early 90's have not proven to reverse or modify this tradition as the Gini coefficient has continued to linger between .50 and .55 .

Undoubtedly, while discussing poverty in Mexico, one must take into account that a large proportion of those living in extreme poverty are found in rural agricultural areas, they are predominantly of indigenous ethnicity and subsistence-farmers. This was the case before trade liberalization in the 90's and it continues to be the case today. In light of this, it is necessary to analyze what occurred to the poor and extreme poor of the Mexican agricultural sector prior to and following trade liberalization.

Land tenure has traditionally been very unequally concentrated and socially divisive issue in Mexican rural areas ever since indepen- 
Figure 2.

Half a century of inequality: 1950-2004

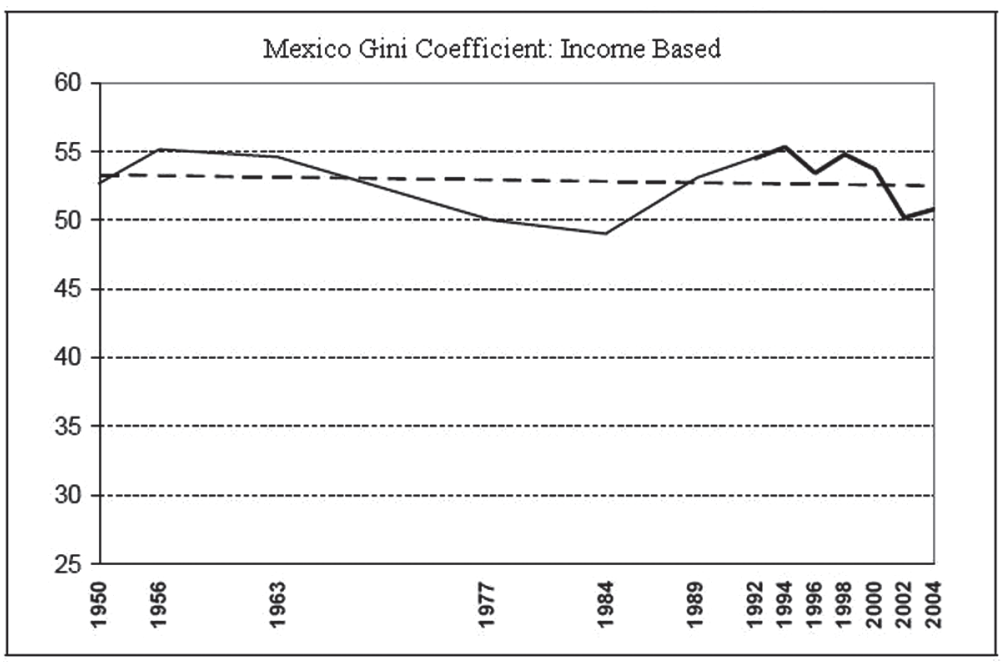

Source: 1950-2000: base WIID2beta de WIDER. 2002, 2004: INEGI.

dence from Spain. The lack of land ownership and the dependency on those who possessed it led indigenous peasants to participate in the armed conflict identified as the Mexican Revolution seeking a distributive land reform. Partially as a result of the Revolution, and a need to maintain social order in rural areas, the Mexican government set in motion a process of distributing landholdings primarily to low-income rural families from the early 1920 's to 1991 . While the beneficiary families did have the right to use the land, they did not have formal ownership of the land, the government retained formal ownership until 1992. There is considerable criticism in regards to the effectiveness of the land distribution policy. A report from the World Bank entitled Government Programs and Poverty in Mexico (2001) affirms that from 1917 to 1991 approximately 100 million hectares of land were distributed, about $50 \%$ of it was arable land, and $75 \%$ of the arable land depended on rain as its main source of irrigation. In addition to this, the size of the parcels distributed communally or individually were quite small. In regards to this, Williams (2004) points out that: "About 50 
percent of Mexico's farmers till plots of 5 hectares or less ( 1 hectare $=2.471$ acres)" (Williams, 2004: 15).

From the historical context presented above we are able to identify some of the current weaknesses facing numerous Mexican farmers coping with free commerce both within North America and internationally, specially the bean and corn producers. That is, they tend to hold small plots of land, thus preventing economies of scale, and their plots are often times not entirely arable and under-irrigated.

Prior to NAFTA, the Mexican government aided farmers by guaranteeing relatively high prices for certain crops like corn, beans and dry milk and they aided urban consumers by providing a subsidy on staple products like tortilla. Several economists and scholars have criticized the lack of effectiveness of the guaranteed pricing policies of the 1970's and 1980's in helping the poorest Mexican farmers. A guaranteed price would only benefit the surplus producers who were able to sell their output in the market while seriously harming subsistence farmers with

Figure 3.

NAFTA prices for corn

\begin{tabular}{lccc}
\hline Year & Canada & Mexico $^{\mathrm{a}}$ & United States $^{\mathrm{b}}$ \\
\hline 1991 & 2.22 & 4.39 & 2.37 \\
1992 & 2.26 & 4.57 & 2.07 \\
1993 & 2.25 & 4.84 & 2.50 \\
1994 & 2.23 & 4.11 & 2.26 \\
1995 & 3.81 & 4.69 & 3.24 \\
1996 & 2.71 & 3.96 & 2.71 \\
1997 & 2.53 & 3.65 & 2.43 \\
1998 & 1.86 & 3.65 & 1.94 \\
1999 & 1.81 & 3.54 & 1.82 \\
2000 & 2.02 & 3.78 & 1.85 \\
2001 & 2.15 & 3.72 & 1.91 \\
2002 & 2.32 & 3.69 & 2.32 \\
2003 & 2.15 & 3.75 & 2.20 \\
\hline
\end{tabular}

a. White corn prices are calculated as weighted average of Conasupo buying prices for producers.

b. Data are average price.

Source: Hufbauer \& Schott (2005: 334). 
small land plots who were traditionally net consumers and thus were forced to buy their lacking agricultural products at higher prices, and yet unable to buy at the subsidized urban prices (Freidman and Legovinim, 1995). Even though corn prices are no longer guaranteed, in Figure 3 we see that, partially due to the lack of competitiveness and productivity of Mexican corn producers, corn remains highly priced relative to Mexico's NAFTA trading partners. Additionally, Hufbauer and Schott (2005) have argued that the Mexican government continues to aid Mexican corn farmers by purchasing corn at higher prices than those found in the international market.

From 1991 to 1995, and in part as a preparation for NAFTA, the Mexican government changed the guaranteed price scheme for a comprehensive set of subsidies, including direct income payments based on hectare of production (Procampo), assistance in achieving greater agricultural productivity by aiding the attainment of modern equipment and technology (Alianza para el Campo) and infrastructure assistance to livestock producers (Produce Capitaliza). In spite of all these programs, Mexican farmers are considerably less subsidized than those in the U.S.

There remains a huge disparity in subsidy levels between the United States and Mexico. During the 1998-2000, for example, average U.S. subsidies given to each agricultural producer amounted to $\$ 20,803$ per year; the comparable Mexican figure was an average $\$ 720$ for each producer. Of course the disparity reflects the fact that on average, U.S. firms are large, run like modern business firms, whereas Mexican firms are small, operated as family enterprises (Hufbauer and Schott, 2005: 296).

As discussed here, the presence and maintenance of extreme poverty in rural Mexico is rooted in the historical context of unequal land distribution, on the quality of land distributed by the government, on the small parcels of subsistence farmers and on the overall unfavorable state of rural infrastructure needed to facilitate the distribution of products. Nonetheless, it is also arguably due to the competition represented by imports of heavily subsidized American producers of key 
products like corn, beans and sorghum who enjoy larger land holdings, better technology and infrastructure to distribute their output. Nonetheless, it is also important to mention that, contrary to what some believe, the NAFTA agreement actually provided a grace period of 14 years before Mexico had to open up completely to imports of corn from the U.S. and Canada. The 14-year transitional period was set so that Mexico could gradually open up to corn imports by expanding the yearly import quotas and slowly adjust to the effects of cheaper corn imports from the U.S. Instead of allowing the gradual rural adjustment foreseen by NAFTA, it was the Mexican government who unilaterally decided to speed up the process and allowed imports of corn over the NAFTA mandated quota almost every year since 1994. Hufbauer et al. (2005) pointed out that this was done in an effort to satisfy the growing demand of corn for the livestock and starch industries as well as to control inflation by allowing greater amounts of cheaper corn into the domestic market. Yet the increase in the international price of corn in response to the thrust to incorporate ethanol as an alternative fuel between 2006 and 2007 has significantly reduced the Mexican government's capability of controlling inflation through importing corn. While the higher corn prices have benefited some Mexican corn producers, the corn surge has been overall damaging to most Mexicans as the price of the tortilla, which constitutes a basic food staple for the bulk of the population, has also augmented and sparked a series of protests in Mexico City early in 2007.

The overall lack of competitivity of Mexican producers in the production of basic crops like corn, sorghum and beans is quite relevant in analyzing rural poverty as about 80 percent of the cultivated land in Mexico is committed to the production of these crops (Wodon, 2001). The importance of infrastructure in explaining the lack of Mexican rural development has been emphasized considerably by Hufbauer et al. (2005: 336): "Poor transportation and irrigation networks are part of the problem. It is three time more costly to deliver corn by rail from Sinaloa to Mexico City than by shipping from New Orleans to Veracruz".

As a result of the low living standards faced by a sizeable proportion of those working in the Mexican agricultural sector, many have 
actually chosen to migrate elsewhere. As seen in Figure 4, total employment in agriculture, hunting, fishing and forestry has dropped from 1997 to 2004 by over 2 million workers. Certainly, this does not mean that prior to NAFTA there was no migration from the rural areas into the cities. Yet the relative lack of competitiveness and profitability involving the production of common crops, in the midst of free trade with the U.S. and Canada, has further provided a significant incentive for farmers to seek better opportunities elsewhere. As pointed out by Williams (2004: 15): "Nearly 80 percent of producers are involved in the production of grains, legumes and oilseeds-Mexico's least profitable crops".

It is also important to point out that not everything has been negative for Mexican agriculture as a result of trade liberalization. Producers of tomatoes, avocados, live cattle, fresh fruits and vegetables have benefited from trade. "A key success story [for Mexico] has been in exports of horticultural products (generally labor-intensive crops that can be grown profitably on smaller farms), which have increased by nearly 120 percent" (Williams, 2004: 15). However, the growth in the exports of selected agricultural products has not been enough to offset the low living standards of rural Mexico nor the persistence of

Figure 4.

Mexico Population employed in Agriculture, Hunting, Forestry and Fishing (in thousands) Classified by employment status

\begin{tabular}{ccccccc}
\hline Total & Employers $\begin{array}{c}\text { Own- Employees } \\
\text { account } \\
\text { workers }\end{array}$ & $\begin{array}{c}\text { Unpaid/ } \\
\text { contributing } \\
\text { family } \\
\text { workers }\end{array}$ & $\begin{array}{c}\text { Not Classified/ } \\
\text { members } \\
\text { of producer's } \\
\text { cooperatives }\end{array}$ \\
\hline 1997 & 9020.1 & n/a & $\begin{array}{c}3568.7 \\
\text { (includes }\end{array}$ & 2762.5 & 2682.2 & 6.7 \\
1999 & 8070.2 & 192.8 & $\begin{array}{c}\text { employers) } \\
\text { 3078.9 }\end{array}$ & 2435.8 & 2361.6 & 1.2 \\
2000 & 6929.1 & 159.7 & 2600.5 & 2361 & 1807.3 & 0.7 \\
\hline
\end{tabular}

Source: International Labor Organization. 
extreme poverty. Even today, agriculture employs around $22 \%$ of the labor force and yet it only generates about $4.4 \%$ of the GDP (Williams, 2004). In light of this, clearly more non-farm employment would help decrease rural poverty by providing small subsistence farmers other work and income possibilities considering that the total income generated by agriculture is excessively marginal in comparison to the amount of people dedicated to it. This is particularly what Williams (2004: 15) argued for:

Economic transition away from agriculture is inevitable for many small-scale agricultural producers. Future policies should focus on generating off-farm employment for those who need it, improving trade opportunities for the 15 percent of Mexico's producers who are globally competitive and improving the productivity of the 35 percent who have the potential to compete.

This was particularly the hope that policy-makers had in 1994 as NAFTA went into effect. Mexican NAFTA negotiators were convinced that agriculture itself could not solve rural poverty nor that it could be solved in rural areas themselves, but rather, the problem required strong job creation in urban areas. They estimated, perhaps too optimistically, that the Mexican economy could easily grow at an average rate of $6 \%$ per year in response to new trade and investment opportunities stemming from the U.S. and Canada upon the enactment of NAFTA (Weintraub, 2004: 11). The rationale was that the establishment of maquiladoras, that is, industrial plants assembling final products intended to be exported for consumption in the U.S. market, as well as other Mexican exporting firms, would provide enough industrial and service jobs to absorb the rural poor. Unfortunately, as we shall see, the overall growth of foreign direct investment and trade, which are components currently considered to be pulling the overall Mexican economy, have not been enough to provide sufficient job growth to significantly assist rural and urban poverty, and have actually been associated with some trends enhancing inequality.

Contrary to initial estimates, the Mexican economy has not been growing at the targeted $6 \%$ per year rate predicted by policy-makers 
in 1994. According to the Economic Commission for Latin America and the Caribbean (2006), the Mexican economy has grown at an average rate of $2.84 \%$ per year from 1994 to 2005. The data for the GDP per capita is even less encouraging. A first glance at Figure 5 may give the impression that the GDP per capita has been somewhat increasing from 1994 to the current estimate for 2007.

Nonetheless, if we take the Mexican GDP per capita growth in context, that is, in relation to other fast-growing regions and countries, we are able to see that Mexico has been considerably lagging behind, specially in relation to South Korea and Ireland. Figure 6 displays the stagnant per capita GDP growth Mexico has displayed since the 1980's, that is, since the first steps were taken toward trade liberalization as Mexico joined the General Agreement on Tariffs and Trade, now referred to as the World Trade Organization, in 1986. Even after joining NAFTA in 1994, GDP per capita growth has continued to be sluggish.

Figure 5.

Mexico Real GDP per capita growth (in 2000 U.S. dollars)

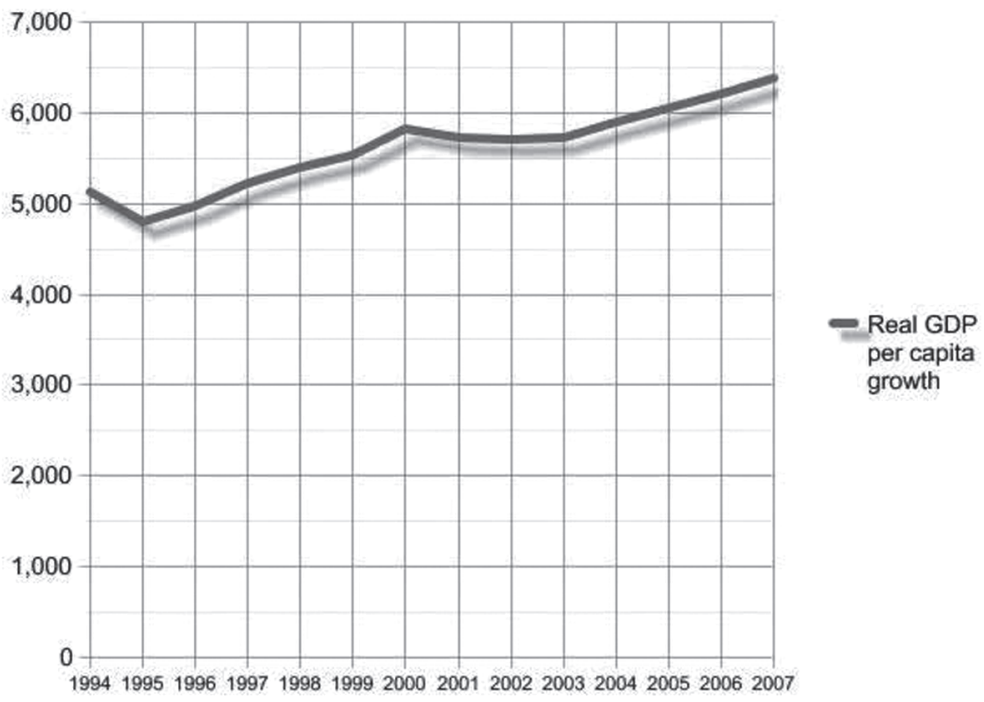

Source: ERS International Macroeconomic Data Set. 
Figure 6.

México GDP per capita growth

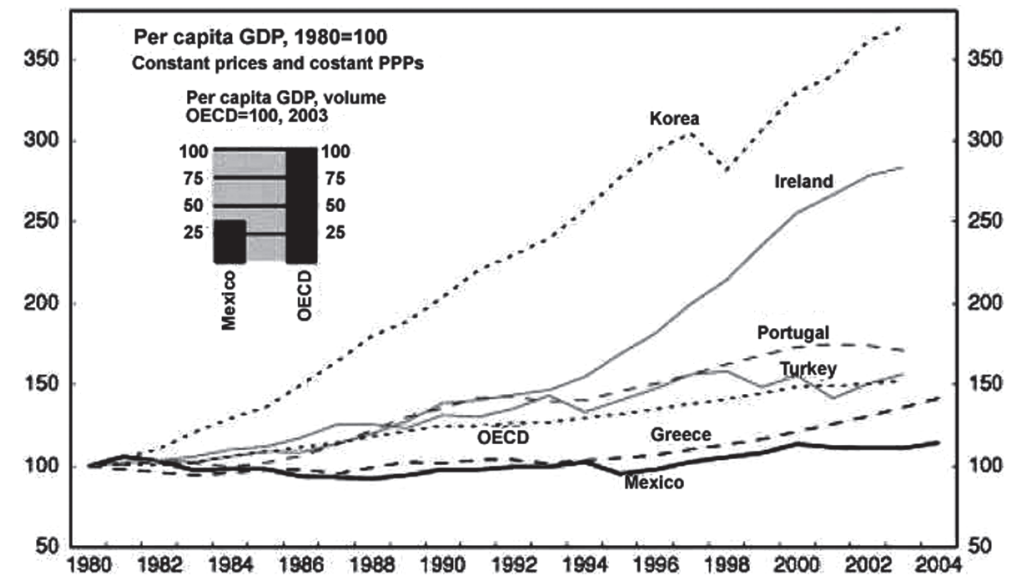

Source: OECD.

Between 1994 and initial estimates for 2007 real GDP per capita growth in Mexico has averaged 1.8\% per year, even less than the real GDP growth.

The slow growth since the early 1990's, both of the real GDP and of the per capita GDP, must be placed in proper context. The financial crisis of 1995-1996 severely hurt employment, overall economic growth and, as seen earlier, it also augmented poverty; in short, it provided a challenging hurdle to surpass early on in the consolidation of Mexico's economic liberalization. In addition to this, it is evident that since the onset of NAFTA trade and investment flows, and their derivative effects, have further and significantly linked Mexico's economy to the economic dynamics occurring in the U.S. As Scott (2004: 314) points out, "NAFTA has certainly deepened the dependence of the Mexican economy on the U.S. economy, in good as well as bad times". During "good times" from 1996 to the year 2000, both economies grew considerably. Likewise, the slower growth rates of the U.S. economy from the end of 2000 up until the end of 2002 were also matched with slow and even negative growth rates in Mexico during the same period of 
time. Furthermore, the potentially slower growth of the U.S. economy towards the end of 2007, associated with trouble in the sub-prime housing market, will also likely induce slower economic growth in Mexico in 2007 (IMF, 2007).

Although the Mexican economy has presented relatively slow growth after NAFTA, some predicted results did actually occur. One of those results was that foreign direct investment fueled into the Mexican economy. Foreign direct investment can be defined as "investment made to acquire lasting interest in enterprises operating outside of the economy of the investor... while the parent enterprise establishes control or significant influence over the foreign affiliate" (UNCTAD, 2007). As seen in Figure 7, foreign direct investment flows have been considerably higher after NAFTA than in the previous years from 1991 to 1993. The data is expressed in millions of U.S. dollars and is based on UNCTAD calculations. From 1994 to 2005, 62\% of all

Figure 7.

Foreign Direct Investment in thousands of U.S. dollars

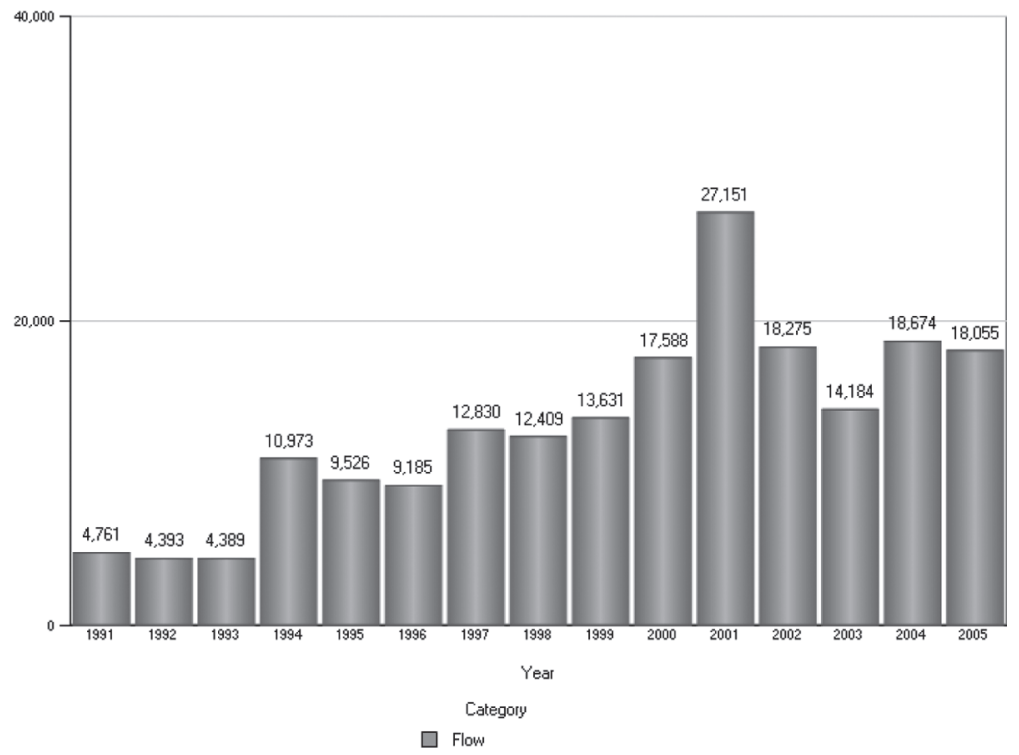

Source: UNCTAD (2007). 
foreign direct investment in Mexico has come from the U.S. (UNCTAD, 2007).

There are, nonetheless, two things that must be mentioned about the flows of foreign direct investment into Mexico. Firstly, the investment has been mostly concentrated in establishing or endowing companies producing goods or services for export back to the U.S. market, such as, for example, the maquiladoras across the U.S.-Mexico border (Weintraub, 2004: 13). The investment has constituted financial flows mainly from the U.S. used to generate products and services for the U.S., which helps explain the deepening of economic ties between the two nations. Secondly, the flows of foreign direct investment have been overwhelmingly directed towards the wealthier regions of Mexico. As shown in Figure 8 the investment has been skewed in favor of Mexico City and the northern regions, while significantly absent from the poorer southern regions of Chiapas, Yucatan and Oaxaca. Mexico City (Distrito Federal in the figure) received almost half of the foreign direct investment in 2006. The concentration of the investment in wealthier and predominantly urban regions has further intensified Mexico's regional disparities. Nonetheless, the concentration simply responds to the fact that the wealthier Mexican urban regions possess the necessary transportation and communication infrastructure as well as the labor pool required to facilitate the exportation of products and services back to the U.S. or elsewhere, which multinational firms and companies in export intensive sectors appear to have a strong demand for (Hanson, 2003: 29).

Trade has followed a similar pattern to that of foreign direct investment. From 1994 to 2005 exports grew from roughly over 60 billion U.S. dollars to over 214 billion. Similarly, imports grew 200\% for

Figure 8.

Distribution of Foreign Direct Investment Selected States (millions of U.S. dollars)

\begin{tabular}{lllllllll}
\hline Total & Chihuahua & $\begin{array}{c}\text { Distrito } \\
\text { Federal }\end{array}$ & $\begin{array}{c}\text { Estado } \\
\text { de México }\end{array}$ & $\begin{array}{c}\text { Nuevo } \\
\text { León }\end{array}$ & Chiapas Yucatán Oaxaca \\
\hline 2006 & $14,638.30$ & $1,319.70$ & $6,563.50$ & $1,142.70$ & $1,347.60$ & 0.2 & 23 & 4.5 \\
\hline
\end{tabular}

Source: INEGI. 
the same period (ECLAC, 2006). However, just as foreign direct investment, foreign trade has also concentrated in the wealthier and more urban regions of the country. Specifically, trade flows have concentrated in the northern industrial states along the U.S.-Mexico border, in Mexico City, in Jalisco and Puebla; whereas poorer rural states with large indigenous populations like Chiapas and Oaxaca have participated only marginally in free trade (Bancomext, 2006). Thus, trade and investment flows since NAFTA have aided to enhance the pre-existing regional disparities between the industrial northern and central regions and the poorer south and southeastern regions.

The enlargement of regional disparities would not in itself be an irreconcilable problem if employment growth in the wealthier regions were strong enough to absorb the extreme poor from urban and rural areas. Nonetheless, this has unfortunately not occurred as job growth has so far been slow, along with the overall lower than expected economic growth. For example, according to Zarsky and Gallagher (2004), from 1994 to 2002 around 6.5 million people entered the Mexican workforce and yet only 4.4 million new jobs were created during the same period, leaving over 2 million people without employment. The hope held by Mexican and American policy-makers that considerable and sufficient economic and job growth could be generated through the expansion of trade and investment encouraged by the ratification of NAFTA has been empirically unfounded. Additionally, international foreign investment and trade have not been able to considerably spur "spillover effects", that is, independent domestic industrial or productive capacity reflected in an increase of technology, skills and knowledge in local firms and workers. These "spillover effects" are considered to be a primary conduit to economic growth in the context of globalization. Zarsky and Gallagher (2004: 6) point out that aside from the auto industry, "most studies since NAFTA have found little evidence of spillovers from FDI in Mexico".

Trade and investment after NAFTA have been unable to foster sufficient, far-reaching and sustained growth to create enough jobs and thus considerably reduce extreme poverty in the country; or as Zarsky and Gallagher (2004) state: "The failure of the manufacturing sector to be an engine for growth means that the FDI-led strategy did little to reduce 
Mexico's large income and asset gap between rich and poor" ("Jobs and Migration"). As a result of the insufficient job growth, many of Mexico's new jobs since 1994 are informal jobs which tend to pay less than formal ones and are generally of poor quality. Zarsky and Gallagher (2004) found that approximately 55 percent of the informal jobs in Mexico created since 1994 do not provide any form of benefits. The net result has been that the limited number of formal jobs in the urban or industrial regions along with the unappealing nature of informal jobs have in fact induced strong incentives for Mexican workers to migrate to the United States in search of better opportunities.

Aside from the cyclical nature of the U.S. economy and its effect on the growth potential of the Mexican economy mentioned earlier, there are other fundamental reasons why economic and job growth have been limited in the post NAFTA years. The first element frequently cited by economists is that while labor costs are much lower in Mexico than in the U.S., they are even lower in China, India, Vietnam and other nations of East Asia. Mexico has increasingly had to compete with East Asia for foreign direct investment flows and for markets to export products and services to. The relative success of East Asian nations in obtaining investments from and exports to the U.S. and elsewhere has hampered in significant ways Mexico's export-led growth model largely dependent on free trade with the U.S. in the post NAFTA years. A recent development that may help to exemplify this is Hitachi's closing of its Guadalajara manufacturing facility in 2007. Hitachi is a multinational provider of a wide range of electronic, power and computer appliances and components. The Guadalajara plant was chiefly dedicated to the manufacturing of hard drives and employed approximately 4,500 people. In March of 2007 the company announced it would close its plant in Guadalajara, Mexico and transfer it to the Philippines in an overall effort to reduce costs (Itnews, 2007).

Lou Dobbs has been influential in bringing this element of globalization and free trade to the American public sphere. In his book titled War on the Middle Class, he argues that the outsourcing of American jobs occurring in the midst of an evermore globalized world with lower trade and investment barriers is actually in detriment of middle-class America. 
It is the rationalization of CEO's of multinationals who have continued to prove that they do not care what happens to the working men and women of this country. Hundreds if not thousands of big America companies are ignoring the needs and interest of their employees and the communities in which they are based by outsourcing work to the communities and citizens of other nations (Dobbs, 2006: 111).

Certainly, as shown by the Hitachi example, we must add to Lou Dobbs argument that the outsourcing trend does not only affect the American middle class, rather it also may affect developing nations whose labor is or becomes comparatively more expensive in relation to the labor of another developing country. The issue is thus a lot more complex and global than Lou Dobbs' defense of the American middle class.

Another factor hampering Mexican economic and job growth frequently discussed by economic and demographic scholars is the population explosion. From 1970 to 2000 the Mexican population nearly doubled and went from 53 million to 100 million while the labor force more than doubled from 15 million to 40 million. In 1974, as a reaction to alarming forecasts of population growth and its derivative effects, the government launched a promotional campaign to promote family planning which helped lower the average number of children per woman from 7 in 1965 to 2.5 in 2000 (Hufbauer and Schott, 2006: 454). The demographic expansion since the 1970's has been coupled with several economic crises, one in the 70's, another one in the early 80's and one in the mid 90's. In short, the demographic growth of the labor force has also been combined with a lack of sustained economic growth, which in turn would enable conditions for job growth. This context helps to explain the surge of Mexico's informal sector and illegal immigration. Demographic growth was already a problem much before NAFTA came into effect. In this regard, the failure of NAFTA has not been its inability to create jobs, after all 4.4 million formal sector jobs were created from 1994 to 2002 and many of those new jobs were in some way linked to expanded trade and investment. Rather, the disappointment has come given that new opportunities originating from free trade and investment with the U.S. and Canada have been unable 
to counteract insufficient work for an expanding labor force. The inability to match the growth of employment with the increasing size of the labor force has also been associated with the challenge of raising average real wages in Mexico; as depicted in Figure 9, national average wages have not increased much in the last ten years.

There are, however, some encouraging population trends. The decreasing fertility rate of Mexican women noted earlier is beginning to display positive trends. For example, according to Hufbauer and Schott (2006), the number of young people yearly entering the workforce will be cut by half between 1996 and 2010, and perhaps even more after that. Under the assumption of even moderate sustained growth, a decrease in the growth of the Mexican labor force could mean that there would be a greater capacity to integrate a larger proportion of the workforce into formal employment. As a result, it is likely that fewer Mexicans would feel compelled to emigrate to the U.S. The potential subsiding of Mexican illegal immigration over two or three decades due to reduction in the growth rate of the labor force, assuming a stable economic context, has been comprehensively contended by Bean and Lowell (2004: 278-279) and Hufbauer et al. (2006: 454455); these scholars claim that incentives to emigrate to the U.S. may very well continue, but the amount of migration itself might diminish sufficiently for it to rouse much less public debate.

Nonetheless, as of now, illegal immigration from Mexico and elsewhere continues to be a key issue within the American public sphere, and Lou Dobbs has been central in bringing attention to the matter. Dobbs argues that: "America has become a nation of broken borders. People enter our country seemingly at will, without regard for our laws. They threaten our safety and security, they use our resources, and they

\section{Figure 9.}

Employee monthly earnings (in pesos of 2000)

\begin{tabular}{lcccccccccc}
\hline & 1995 & 1996 & 1997 & 1998 & 1999 & 2000 & 2001 & 2002 & 2003 & 2004 \\
\hline $\begin{array}{l}\text { National } \\
\begin{array}{l}\text { average } \\
\text { earnings }\end{array}\end{array}$ & 3067.87 & 2559.82 & 2550.74 & 2631.29 & 2628.59 & 2939.40 & 3111.56 & 3167.32 & 3245.98 & 3245.54 \\
\hline
\end{tabular}

Source: Estimates based on data from the International Labor Organization. 
take our jobs" (Dobbs, 2006: 134). As observed in Figure 10, the amount of both Mexican immigrants and apprehensions of illegal Mexican immigrants has increased considerably since the 1980's, a trend which has anything but subsided in the post-NAFTA years. The increased amount of illegal immigrants, mostly of Mexican origin, has sparked heated debate as to what their effect is on the economy in general and in wages and public services in particular.

Two economists leading the public debate on the effects of immigration are David Card from University of California, Berkley, and George Borjas from the John F. Kennedy School of Government. Their contrasting views are considered and juxtaposed in the New York Times editorial of July 9, 2006. On one side, Card argues that the idea that illegal immigrants abuse the public system's resources is inaccurate.

Figure 10.

Mexican Inmigration and apprehensions, 1890-2003

\begin{tabular}{|c|c|c|c|c|}
\hline \multirow[t]{2}{*}{ Decade } & \multicolumn{2}{|c|}{ Number of inmigrants } & \multirow{2}{*}{$\begin{array}{l}\text { Decade as percent } \\
\text { of } 1890-2000 \text { total }\end{array}$} & \multirow{2}{*}{$\begin{array}{c}\text { Deportable aliens } \\
\text { decade total }\end{array}$} \\
\hline & $\begin{array}{l}\text { Annual } \\
\text { average }\end{array}$ & $\begin{array}{c}\text { Decade } \\
\text { total }\end{array}$ & & \\
\hline $1890-1900$ & 97 & 971 & 0 & n.a. \\
\hline 1901-1910 & 4,964 & 49,642 & 1 & n.a. \\
\hline 1911-1920 & 219,000 & 219,004 & 4 & n.a. \\
\hline 1921-1930 & 45,929 & 459,287 & 8 & 128,484 \\
\hline 1931-1940 & 2,232 & 22,319 & 0 & 147,457 \\
\hline 1941-1950 & 6,059 & 60,599 & 1 & $1,377,210$ \\
\hline 1951-1960 & 22,981 & 229,811 & 4 & $3,598,949$ \\
\hline 1961-1970 & 45,394 & 453,937 & 8 & $1,608,356$ \\
\hline 1971-1980 & 64,029 & 640,294 & 11 & $8,321,498$ \\
\hline 1981-1990 & 165,584 & $1,665,843$ & 27 & $11,883,328$ \\
\hline 1991-2000 & 224,942 & $2,249,421$ & 37 & $14,667,599$ \\
\hline 2002 & 219,380 & n.a. & n.a. & n.a. \\
\hline 2003 & 115,864 & n.a. & n.a. & n.a. \\
\hline Total & n.a. & $6,041,118$ & 100 & $41,732,881$ \\
\hline
\end{tabular}

n.a.= not applicable

Note: Deportable aliens are measured by apprehensions, which in turn record events, so one person caught three times is three apprehensions; 95 to $98 \%$ of those apprehended are Mexicans.

Source U.S. Department of Homeland Security, Yearbook of Inmigration Statistics (2003). 
Unauthorized immigrants pay property taxes directly or indirectly by renting or owning a house in the U.S., they also pay sales taxes when purchasing products and services. They also contribute to the U.S. Treasury given that they usually utilize false Social Security numbers and thus pay contributions which they cannot ever claim back. In addition to this, less than $3 \%$ of all illegal immigrants received food stamps (Lowenstein, 2006: 39). On the other hand, Borjas argues that it is strictly unwise to allow such large inflows of poorly educated Mexicans. Additionally, Borjas has empirically studied the relationship between illegal immigrants and the wages of high school dropouts in the U.S. from 1960 to 2000. His conclusion is that wages for high school dropouts fall 3 to $4 \%$ for each $10 \%$ increase in the share of immigrants. Peri, working at the University of California, Davis, actually replicated Bojas' study and adjusted the model taking into account certain wage gains that unskilled Americans may receive from the influx of illegal immigrants. That is, for example, if a large number of illegal immigrants come to work in construction, then some unskilled workers may be hurt, but others may get promoted because more crews mean a greater need for more crew supervisors. According to Peri, as paraphrased in Lowenstein (2006: 69), when these developments are taken into account, illegal workers harm unskilled American wages by around 1\%. To this, Card adds that it is quite difficult to isolate the effect of illegal immigrants on wages of uneducated American workers because there are so many factors influencing those wage rates like globalization, changes in the minimum wage, outsourcing, etc. Card is also keen to point out that beyond economics, "[...] darker forces-ethnic prejudice, maybe, or fear of social disruption- is what is really motivating a lot of anti-immigrant sentiment" (Lowenstein, 2006: 43). Furthermore, in a different editorial article dated Dec. 18, 2006, the New York Times claims that if raids to catch illegal immigrants were systematic and not simply symbolic, the American economy could not stand the shock (p. A26).

While there is a public debate on to what extent unauthorized immigration enhances wage declines and inequality in American society, there is also a linked discussion as to whether remittances cause inequality in the poor rural regions where Mexican migrants come 
from and where some of their family members live. Initial studies showed that remittances were associated with inflation in the migrant rural communities as family members of migrant workers who received funds from them were able to increase overall local demand for products and services. This resulted in an unfair circumstance for those rural inhabitants who did not have migrant family members and thus contributed to inequality. Nonetheless, as more members of the rural communities began to receive remittances, the overall living standards of those rural villages and towns rose, as more funds stemming from remittances would circulate in the local economy. In a recent study regarding the relationship between remittances, inequality and poverty, Lopez-Feldman et al. (2005: 25-26) concluded that remittances from international migrant workers become less unequalizing and more effective at reducing poverty as the prevalence of migration increases in a specific Mexican rural region; and that furthermore, international remittances reduce poverty by a greater amount than internal remittances.

While the effects of remittances on inequality may be subsiding because of an increase in the total number of international migrant workers from rural and some urban areas, the widening difference in the compensation allocated to employees possessing higher and lower levels of educational attainment ever since the beginning of trade liberalization in the 1980's has been identified as a factor contributing to the Mexico's inequality. As seen on Figure 11, there appears to be overall slight improvements in the educational attainment of the Mexi-

Figure 11.

Distribution of Labor Force according to Highest Level of Educational Enrollment

\begin{tabular}{cccccccc}
\hline Year & $\begin{array}{c}\text { Total } \\
\text { Labor } \\
\text { Force }\end{array}$ & $\begin{array}{c}\text { No } \\
\text { Schooling }\end{array}$ & Primary & $\begin{array}{c}\text { Lower } \\
\text { Secondary }\end{array}$ & $\begin{array}{c}\text { Upper } \\
\text { Secondary }\end{array}$ & $\begin{array}{c}\text { Post Secondary/ } \\
\text { Non Tertiary }\end{array}$ & Tertiary \\
\hline 1996 & 36.6 million & $9 \%$ & $41 \%$ & $21 \%$ & $16 \%$ & $1 \%$ & $12 \%$ \\
2005 & 42.8 million & $7 \%$ & $32 \%$ & $26 \%$ & $13 \%$ & $6 \%$ & $16 \%$ \\
\hline
\end{tabular}

Source: LABORISTA, International Labor Organization. 
can labor force between 1996 and 2005. In comparison to 1996, in 2005 there was a lower proportion of the labor force whose highest level of educational enrolment was either primary or no formal schooling. However, the proportion of the labor force attaining or enrolled in tertiary education in 2005 is still low compared to roughly $60 \%$ in the U.S. according to the LABORISTA database of the International Labor Organization.

In spite of the slight improvements in the overall education attainment of the Mexican labor force, there is a link between the opening up of free trade and a widening gap in wages between the more educated and the less skilled workers. Legovini, Bouillon and Lustig (2001: 28-29) analyzed the relationship between growing wage inequality and education in Mexico from 1984, once Mexico began lowering barriers to free trade in several industrial categories after joining the GATT [now the World Trade Organization], to 1994. They concluded that changes in the wages of workers with different educational levels, associated with technological change and trade liberalization, were responsible for about two fifths of the rise in inequality. Hanson (2003) affirms that the trend involving increasingly disproportional returns to skilled labor in relation to unskilled labor continued and intensified after the ratification of NAFTA in 1994. Part of what explains this trend is that prior to trade liberalization in the beginning of the $80^{\prime} \mathrm{s}$, Mexico's most protected industries were labor-intensive, employing a considerable amount of unskilled labor. After the early 80's and particularly after the signing of NAFTA, as these firms in several protected industries were challenged by the lower prices of international competitors, their ability to employ personnel or raise wages became increasingly difficult. Yet more significantly, Aitken, Harrison and Lipsey found that "controlling for plant, industry and region characteristics, manufacturing plants that are foreign-owned pay their skilled workers 21.5 percent more and their unskilled workers 3.3 percent more than in plants that are domestically owned" (paraphrased in Hanson, 2003: 9).

Moreover, Scott (2004) argues that the unequalizing impact of significantly higher returns to education is a phenomenon associated with trade liberalization and is partly due to an increasing demand for educated labor in evermore globalized and technologically-intensive mar- 
Figure 12.

Tertiary Education

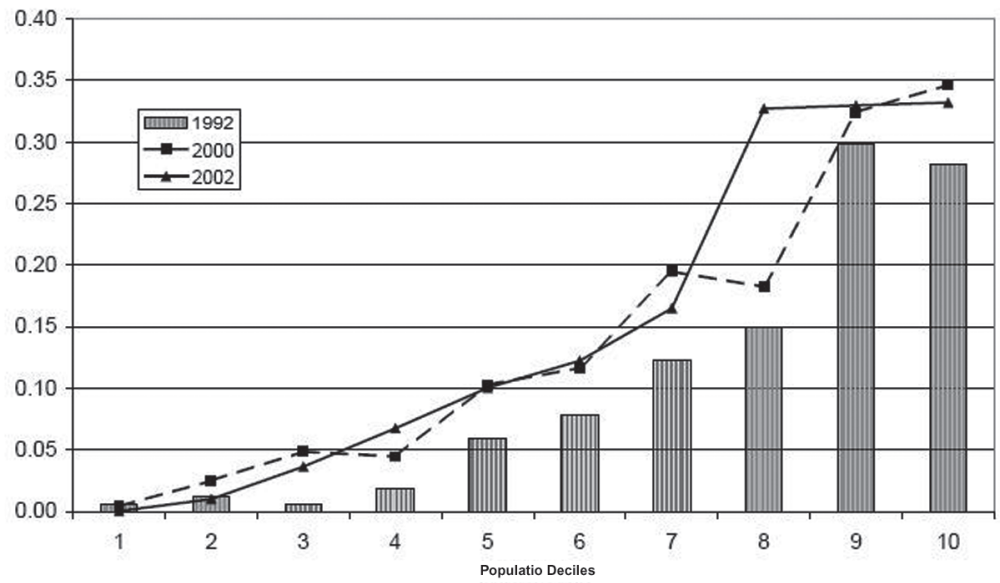

Source: ENIGH (1992, 2000, 2002). Population deciles ordered by per capita expenditure.

kets. In other words, the significant benefits of education in terms of earnings are found mostly at the higher levels which, as of now, are mostly accessible to the higher income groups of the nation. Legovini et al. (2001) argue that this circumstance presents families facing extreme poverty in rural areas with difficult choices as they need income that their children could earn, especially after the age of 15 , and spending their funds to help their children study at a university, typically in a different locality, presents a serious sacrifice. Figure 12 illustrates exactly how difficult it is for the lower income groups to access tertiary education. The wealthiest $9^{\text {th }}$ and $10^{\text {th }}$ population deciles account for almost $70 \%$ of tertiary enrollment, while the access of the poorest deciles, i.e. the first and second, remain virtually unchanged since 1992.

Figures such as this last one have helped to bring to the public debate the effectiveness of public spending in alleviating poverty. This has been a constant topic of discussion in the Mexican public sphere as it concerns the allocation and redistribution of taxed funds. In regards to this, Corbacho and Swchartz (2002: 11) argue that "Lagging 
rural development and a strong pro-urban public expenditure bias have frequently been indicated as being at the root of Mexican poverty and inequality". Unfortunately, there is some evidence supporting this claim. In Figure 13, we observe that Distrito Federal (Mexico City) receives a far greater proportion of per capita resources in comparison to Chiapas, Guerrero and Oaxaca, some of the nation's poorest states (World Bank, 2005). Understandably, given the migration to cities and given the concentration of international trade and investment in some of the northern cities, Mexico City and Guadalajara, it is somewhat natural to expect that some of these cities demand more public spending to accommodate these developments. In addition to this, the conventional wisdom during much of the 1990's was precisely that the export-led growth of the cities would absorb the rural poor. It was this view that justified skewed public spending in favor of cities and thus also in favor of the middle and higher income deciles that tend to inhabit them.

Figure 13.

Geographic distribution of per capita resources

2002-2004

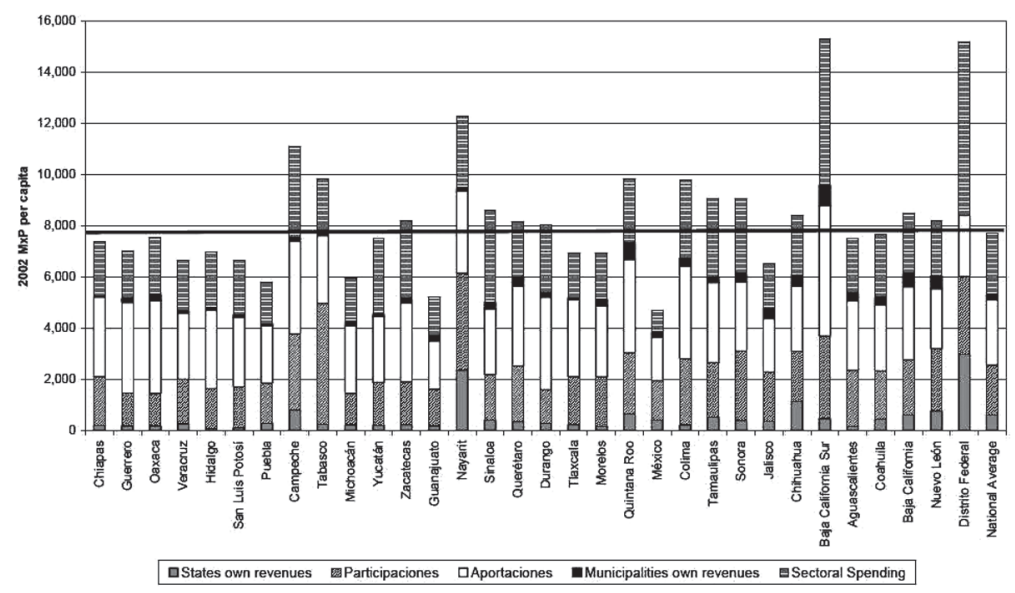

Source: World Bank Estimates. 
Figure 14.

Distribution of Procampo Transfers, 1994-2002

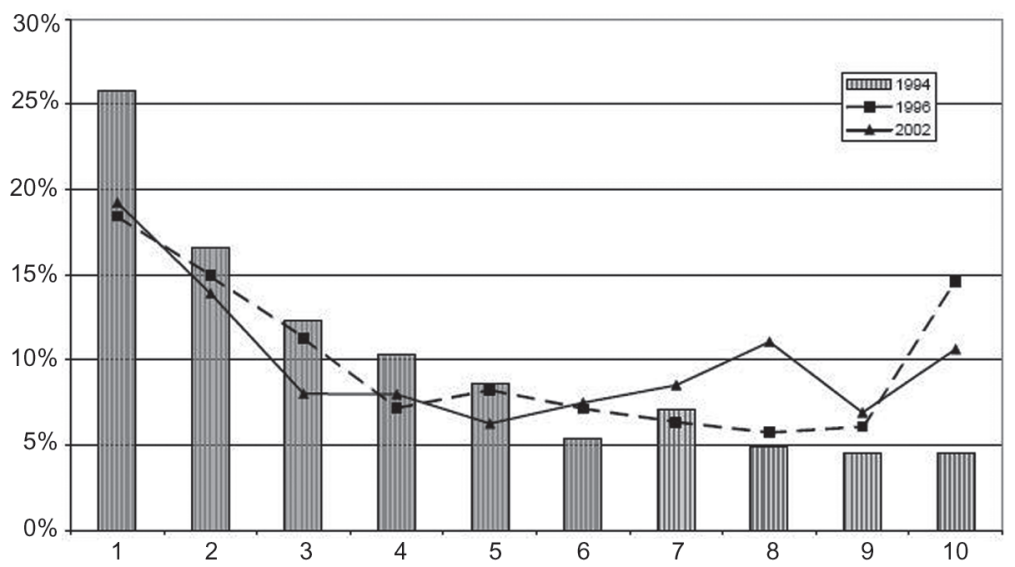

Source: ENIGH (2002). World Bank calculations.

Figure 15.

Distribution of Public Expenditure on Health Services, 2002

\begin{tabular}{cc}
\hline Decile & $\begin{array}{c}\text { All public } \\
\text { expenditure }\end{array}$ \\
\hline 1 & $7.7 \%$ \\
2 & $7.4 \%$ \\
3 & $9.5 \%$ \\
5 & $8.6 \%$ \\
6 & $10.7 \%$ \\
7 & $10.7 \%$ \\
8 & $10.7 \%$ \\
9 & $12.2 \%$ \\
10 & $12.3 \%$ \\
Urban & $10.1 \%$ \\
Rural & $70.9 \%$ \\
\hline
\end{tabular}

Source: ENIGH (2002) and table 2.3. Population deciles are ordered by per capita expenditure. 
In Figure 14 we observe the distribution of the PROCAMPO spending, a government program explicitly directed at helping the rural groups and especially those heavily affected by the opening up of trade. The distribution of PROCAMPO funds was actually more in favor of poorer income groups in 1994 than it was in 2002. In Figure 14 we see that in 1996 as well as in 2002 PROCAMPO transfers, based on hectare of cultivated land, also served higher income farmers considerably as in 2002 the wealthier $8^{\text {th }}$ and $10^{\text {th }}$ population deciles received more PROCAMPO aid than what was given individually to the poorer $3^{\text {rd }}, 4^{\text {th }}$, and $5^{\text {th }}$ deciles. Additionally, health spending also seems skewed to favor higher income families. In Figure 15 we see that health expenditure favors the wealthier $8^{\text {th }}, 9^{\text {th }}$ and $10^{\text {th }}$ population deciles more than the $1^{\text {st }}, 2^{\text {nd }}$ and $3^{\text {rd }}$ ones.

Certainly, some of these orientations in public spending need to be addressed, specifically as it concerns improvements in infrastructure, health and education. Yet this in itself will be a difficult challenge as the Mexican government is currently financing around 40 percent of total expenditure with oil revenue from Pemex, the publicly owned Mexican oil company. As indicated by Dickerson (2007) from the Los Angeles Times, Pemex has a bit more than a decade worth of known reserves, consequently, president Calderón knows he must allow the company to reinvest more funds into research and development. Thus, in order to continue tackling poverty and inequality, taxes must be raised in some way or another, possibly by applying a sales tax to currently exempt medicine and food items, a politically divisive move which former president Fox failed to pass through a polarized congress.

To conclude, contrary to common views often depicted in the media, trade liberalization in general, and NAFTA specifically, has not been the cause of or the solution to the alleviation of poverty and inequality in Mexico. As mentioned in the text, the emergence and presence of extreme poverty is tied to the historical problem regarding the concentration of land and the subsequent distribution of small plots of land, often times unfit for profitable agriculture, to a large mass of peasants. The emergence of free trade in Mexico beginning in the 1980's and consolidating after the enactment of NAFTA in 1994 has caused 
detriment to selected labor-intensive industries and farmers of crops such as corn and beans. On the other hand, the expansion of investment and trade induced by NAFTA has undoubtedly also provided many opportunities throughout the economy, but as Hanson (2003: 29) pointed out, "Overall, the workers in Mexico that have fared the best in the country's newly globalized economy are those with relatively high skill levels living in regions with relatively good access to foreign markets". Unfortunately, the opportunities which arose from opening up the Mexican economy to North America were insufficient to fully absorb the extreme poor and those hurt by the emergence of free trade. Partly, the lack of correspondence between job growth and the demand for jobs has been due to large numbers of young Mexicans adding to the labor force each year caused by Mexico's high fertility rates prior to the mid 1970's. As mentioned before, there are some encouraging trends as the growth of the labor force is projected to slow down considerably within one decade responding to lower fertility rates in the 1980's and 1990's. As a result, it is likely that more formal jobs will be increasingly available to a greater proportion of the labor force, thus potentially diminishing the need for Mexicans to participate in the informal economy and to migrate to the United States.

There are, however, sources of public concern in regards to diminishing poverty and inequality in the midst of a globalized Mexican economy. Free trade and more open investment opportunities with NAFTA partners have tended to concentrate benefits disproportionately in the relatively richer areas of Mexico and enhance the compensation granted to the higher educated population. In conjunction to this, during the consolidation of free trade since the early 1990's government spending has shown a bias towards urban areas while social spending has not altogether been benefiting poorer income groups the most. As a result, it has been increasingly difficult for poorer and rural segments of the population to enter tertiary education. In response to this, the World Bank (2005) recommended that Mexico needs to increase social spending and improve the targeting of the social programs in order to allocate more resources to the poorest populations, effectively increasing their ability to participate in and receive benefits from a more globalized economy. The most serious challenge to accomplish this rests on 
the excessive reliance of Mexican public expenditure on finite oil revenues from Mexico's public-owned oil monopoly. The diminishing oil reserves have put pressure on president Calderon's administration to increase non-oil public revenue. President Calderón's ability to negotiate a comprehensive tax reform which does not overwhelm Mexico's poor while readjusting social spending to become progressively inclined toward aiding lower income groups in education, health and infrastructure will be at the core of Mexico's struggle against poverty and inequality.

Undoubtedly, the matter which most ties the persistence of Mexican poverty and inequality after trade liberalization to the American public sphere is the issue of illegal immigration. While much remains to be done on behalf of the Mexican government and private sector to diminish poverty in Mexico, it is also compelling to note that there is a wide difference between what Milton Freidman terms the "power of choice" given to firms in the context of free trade versus that given to individuals. Under NAFTA, multinational firms in Canada, Mexico and the U.S. are relatively able to allocate their financial and productive resources in the most cost-efficient locality in North America in order to maximize their profits. Yet, labor is not given the "power of choice" to maximize their income by being able to work wherever compensation is highest for their skill. The opening of the American labor market to Mexican workers is an issue of extreme divisiveness in the U.S. and currently seems politically impossible, especially in the context of America's security concerns. It seems likely that for some foreseeable years Mexican workers will only have few legal options to immigrate to America, such as the guest worker programs and the limited scope of the TN (NAFTA) visas for highly skilled Mexicans and Canadians, which do not lead to the possibility of permanent residency as the H1B visa does. While there are demographic trends forecasting a reduction in the number of Mexican immigrants in upcoming years, so long as the employment and compensation expectations are so divergent in both nations, so long as there are organized groups willing to facilitate the infiltration of immigrants for a profit, and so long as the presence of illegal workers is not perceived as an overwhelming detriment to the U.S. economy, illegal immigration from 
Mexico to the U.S. will continue and not cease to form part of an evermore complex debate regarding poverty and inequality in America's southern neighbor.

\section{References}

Ahmed, Maria (2006), "Free and Fair Trade”, Global Agenda, p. 111. Bancomext (2006), "Información de Sectores. Estadísticas e Informes", retrieved April 21, 2007 from http://www.bancomext.com/ Bancomext $/$ portal $/$ portal.jsp?parent $=8 \&$ category $=40 \&$ document $=7200$.

Bean, Frank \& Lindsay Lowell (2004), "NAFTA and Mexican Migration to the United States", in Weintraub (ed.), NAFTA's Impact on North America: The first decade (263-284), Washington D.C., CSIS Press.

Bensusan, Graciela (2004), "Labor Regulations and Trade Union Convergence in North America", in Weintraub (ed.), NAFTA's Impact on North America: The first decade (123-155), Washington D.C., CSIS Press.

Cassidy, John (2006), "Relatively Deprived: How poor is poor?", The New Yorker. Retrieved April 22, 2007, from http://www. newyorker.com/archive/2006/04/03/060403fa_fact

Corbacho, Ana \& Gerd Schwartz (2002), Mexico: Experiences with ProPoor Expenditure Policies, Washington, D.C.: International Monetary Fund.

Dickerson, Maria (2007), "Mexico Needs to Overhaul Tax Collection", LosAngeles Times, March 17 $7^{\text {th }}$ retrieved on April 3, 2007 from http:/ /www.latimes.com/business/taxes/la-fi-mextax17mar17, 1,646353.story? page $=1 \&$ coll $=$ la-headlines-business-taxes \& ctrack $=2 \&$ cset $=$ true

Dobbs, Lou (2006), War on the Middle Class: How the Government, Big Business and Special Interest Groups are Waging War on the American Dream and How to Fight Back, New York, Viking.

Economic Commission for Latin America and the Caribbean (2006), México: Estudio Económico 2005-2006, Santiago, Chile, Economic Commission for Latin America and the Caribbean. 
Economic Commission for Latin America and the Caribbean (2005), Social Panorama Report, Santiago, Chile, Economic Commission for Latin America and the Caribbean.

Freidman, Lustig \& A. Legovini (1995), "Mexico: Social spending and Food Subsidies during Adjustment in the 1980's", in Copying with Austerity, N. Lustig (ed.), Washington, D.C., Brookings Institute Press.

Freidman, Milton (1962), Capitalism and Freedom, Chicago, The University of Chicago Press.

Galbraith, John Kenneth (1976), The Affluent Society, Boston, Houghton Mifflin Company.

Habermas, Jurgen (1993), The Structural Transformation of the Public Sphere: An inquiry into a Category of Bourgeois Society, Massachussets, Massachussetts Institute of Technology.

Hanson, Gordon (2003), What has happened to Wages in Mexico since NAFTA? Implications for Hemispheric Free Trade, San Diego, California, National Bureau of Economic Research, Inc.

Hufbauer, Gary Clyde \& Jeffrey J. Schott (2005), NAFTA Revisited: Achievements and Challenges, Washington D.C., Institute for International Economics.

International Monetary Fund (2007), World Economic Outlook: Spillovers and Cycles, Washington, D.C., International Monetary Fund.

ITnews (2007, March 26), "Hitachi closes hard drive plant in Mexico", Itnews.com.au, March 26 $6^{\text {th }}$ retrieved on April 3, 2007 from http:/ / www.itnews.com.au/newsstory.aspx?CIaNID=48492\&r=rss Legovini, Arianna, Cesar Bouillon \& Nora Lustig (2001), Can Education Explain Changes in Income Inequality in Mexico?, Washington D.C., Inter American Development Bank.

Lopez Feldman, Alejandro, Richard Adams, Jorge Mora \& Edward Taylor (2005), Remittances, Inequality and Poverty: Evidence from Rural Mexico, San Diego, California, Giannini Foundation for Agricultural and Resource Economics.

Lowenstein, Roger (2006), "What is she doing to American jobs and wages?, The New York Times Magazine, July 9th , pp. 35-71. 
Scott, John (2004), "Poverty and Inequality", in Weintraub (ed.), NAFTA's Impact on North America: The first decade (307-337), Washington D.C., CSIS Press.

The New York Times editorial (2006), "Swift Raids", The New York Times, December $8^{\text {th }}$, p. A26.

United Nations Conference on Trade and Development (2007), "Foreign Direct Investment. Definitions and Sources". Retrieved April 21 from http:/ / owl.english.purdue.edu/owl/resource/560/10/ United Nations Development Programme (2006), Human Development Report, New York, UNDP.

Weintraub, Sidney (2004), NAFTA's Impact on North America: The first decade, Washington D.C., csisPress.

Williams, David (2004, January), "Mexico's NAFTA Experience", AgExporter, January, pp. 14-15.

Wodon, Quetin (2001), Government Programs and Poverty in Mexico, Washington, D.C., World Bank Publications.

World Bank (2005), Mexico: Income Generation and Social Protection for the Poor, Washington, D.C., World Bank Publications.

Zarsky, Lyuba \& Kevin Gallagher (2004), NAFTA, Foreign Direct Investment, and Sustainable Industrial Development in Mexico, Silver City, New Mexico, Iterhemispheric Resource Center. 